\title{
Hydrodynamics and particulate matter budget of Königshafen, southeastern North Sea
}

\author{
G. Austen \\ Forschungs- und Technologiezentrum Westküste, \\ Außenstelle der Christian-Albrechts-Universität zu Kiel; \\ Hafentörn, D-25761 Büsum, Federal Republic of Germany
}

\begin{abstract}
A basic control mechanism for the input and output of materials in the Königshafen, a sandy backbarrier embayment, is the action of the tides. Thus, the description of the hydrodynamic conditions provides basic information for further investigations in the Königshafen. On the tidal flats and in the western part of the tidal creek, the near-bottom residual currents are weakly flooddominated. In the other parts of the tidal creek, the flood and ebb currents are well balanced. During high tide, the suspended matter shows an increase towards the inner part of the bay. The concentration of suspended matter, its distribution and the currents are influenced by wind action. During westerly winds up to 4-5 Beaufort, the concentration of suspended matter in the embayment varies between 1 and $15 \mathrm{mg} \mathrm{I}^{-1}$. During storms with westerly winds, the near-bottom residual currents are orientated into the bay, and the concentrations increase by a factor of about 2 . Strong easterly winds in combination with a water level of $0.5 \mathrm{~m}$ below mean high water level and an increasing wave energy cause considerable resuspension on the tidal flats of the Königshafen embayment. For this reason, the concentration of suspended matter increases by a factor of about 20 .
\end{abstract}

\section{INTRODUCTION}

The exchange of particulate matter between the North Sea and the Wadden Sea was investigated in a sandy, sheltered tidal embayment within the Sylt-Rømø tidal catchment area in the Königshafen. Different parameters and their interaction were directly measured, e.g. the in- and output of suspended matter, its distribution at defined points of time, as well as the hydrodynamic parameters. Questions to answer included whether a precipitation of suspended matter out of the water column or a resuspension from finegrained sediment takes place in parts of the bay and to what extent these processes are influenced by episodic events such as storms.

\section{STUDY AREA}

The study area is located in the Danish-German Wadden Sea between the islands of Sylt and Rømø, situated in the southeastern North Sea (Fig. 1). Both Sylt and Rømø are connected to the mainland by causeways. The exchange of water masses and particles with the North Sea is restricted therefore to the "Lister Tief", a tidal inlet between the northern tip of Sylt and the southern edge of Rømø. The inlet is about $2.5 \mathrm{~km}$ wide and 


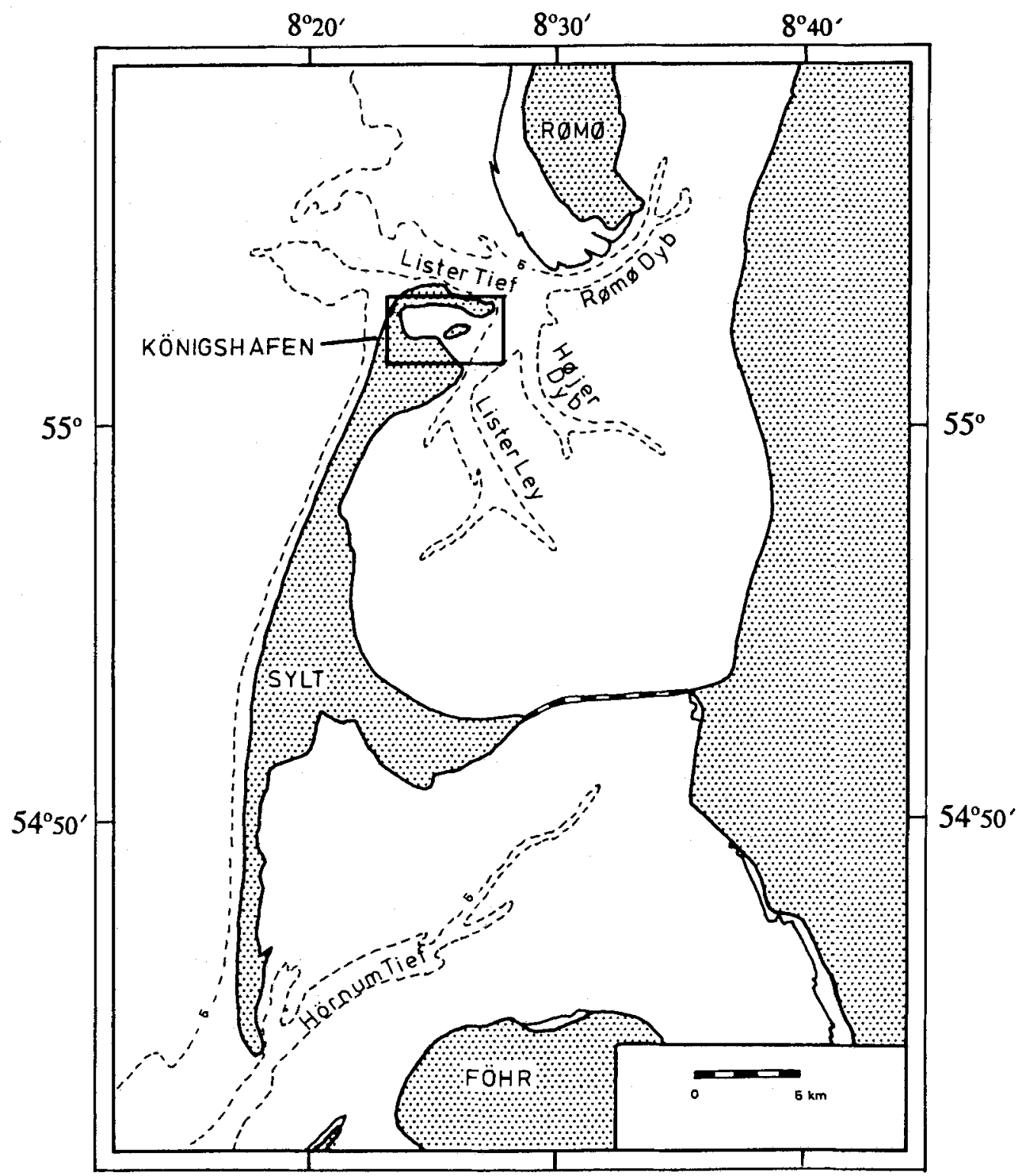

Bathymetry relative to German hydrographic chart datum (SKN)

Fig. 1. Location map of the Sylt-Rømø Wadden Sea region

over $35 \mathrm{~m}$ deep. The tidal catchment drains through the "Rømø-Dyb", "Højer-Dyb" and "Lister Ley" tidal channels.

Preliminary investigations were carried out in Königshafen, an embayment at the northern tip of the island of Sylt (Fig. 2). The Königshafen embayment is enclosed on three sides, being connected to the Lister Ley to the east. The embayment covers an area 


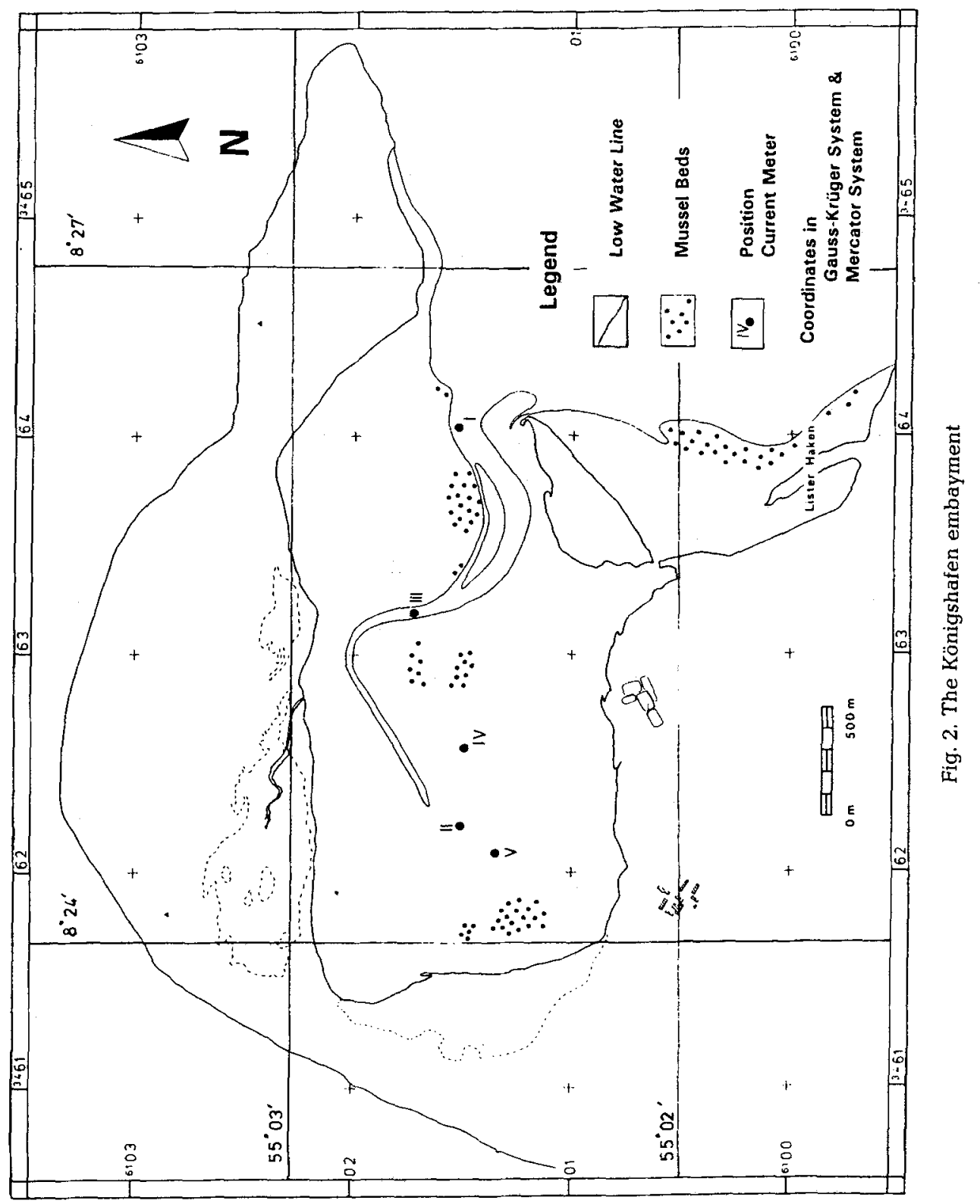


of $8 \mathrm{~km}^{2}$. A curved tidal creek crosses Königshafen. The tidal flats rise regularly towards the shorelines. At high tide the water depth above the tidal flats varies between 0.5 and $1 \mathrm{~m}$ and reaches $4-5 \mathrm{~m}$ in the creek region.

\section{MATERIAL AND METHODS}

Currents were measured by means of Aanderaa current meters. Operating autonomously for up to two weeks, they were fixed to specially designed ground racks so that the sensors were positioned $15-20 \mathrm{~cm}$ above the sediment. The current meters were installed at five different stations during several measuring campaigns in 1990 and 1991 (Fig. 2). These investigations were supplemented by current measurements covering whole tidal cycles from a survey boat anchored at different positions in the tidal creek. Idealized current paths and residual currents (Göhren, 1969) were calculated from the data to obtain a synoptic view on the current processes at the various stations.

The concentration of suspended matter was recorded indirectly using an attenuation sensor (Hydro-Bios). This attenuation sensor was specially built for a water depth up to $10 \mathrm{~m}$. The turbidity readings (\% attenuation) were converted into $\mathrm{mg} \mathrm{l}^{-1}$ suspended matter on the basis of a calibration equation, which was newly provided for each measurement campaign. For that reason, water samples were taken and filtered in the laboratory (glass microfibre filters, pore-diameter $0.7-2.7 \mu \mathrm{m}$, sample volume 1 litre). One of the calibration curves is shown in Figure 3.

The transmission of the water was measured at high tide from a small boat at 30 stations which were regularly distributed over the bay. The position of the boat was fixed with the Decca-System. The values for the longitudes and latitudes were converted into

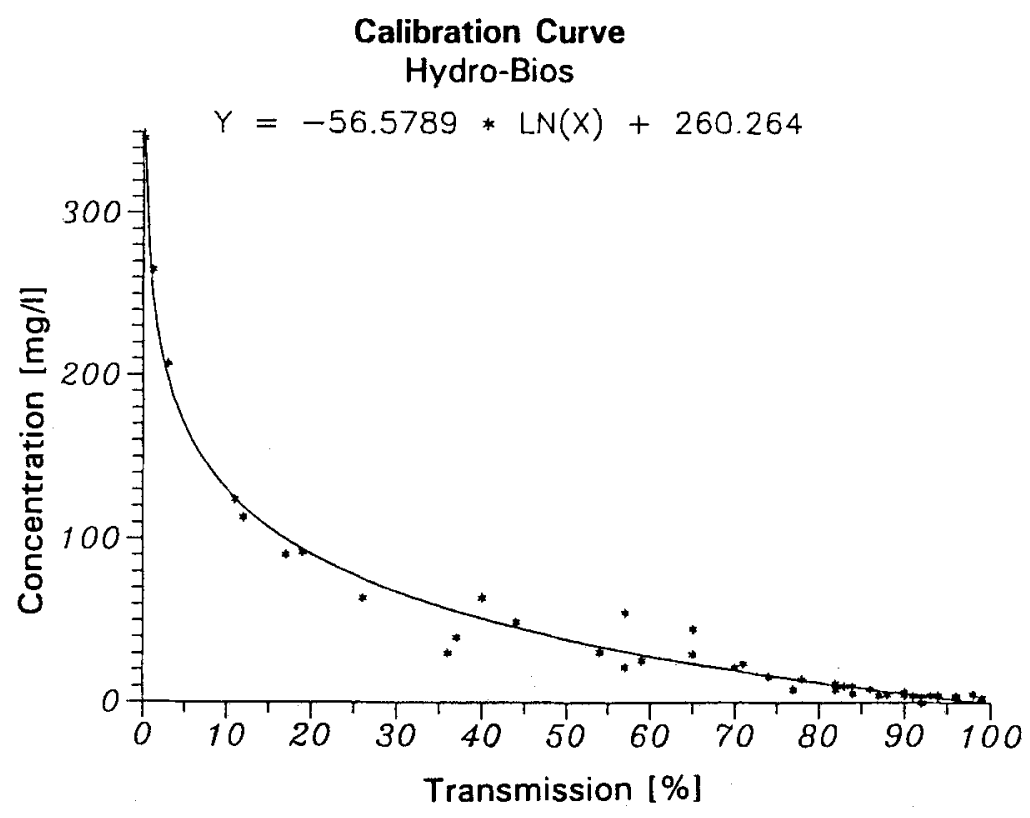

Fig. 3. Calibration curve, attenuation sensor (Hydro-Bios) 
the Gauss-Krüger-System to obtain distances in x- and y-direction in metres (Fig. 2). In this way, quasi-synoptic concentration maps of suspended matter in the near-surface water body at high tide were produced (calculated and plotted with the programm Surfer, Golden Software). Granulometric analyses of the suspended matter were performed by means of a laser-granulometer (CIS, Galai). The grain size of the suspended matter was measured with the CIS-laser granulometer without any preparation.

\section{RESULTS}

\section{Current measurements}

The tidal curve on the tidal flats is typically asymmetrical. At all stations, the highest nearbottom velocities were measured in the first third of the flood cycle. The maximum current velocities varied from 0.3 to $0.5 \mathrm{~m} \mathrm{~s}^{-1}$, depending on the location. Higher velocities were only measured in the relatively deep head region of the tidal creek. Maximum current velocities decrease towards the upper sandy tidal flats. At the beginning of the flood tide the current-direction above the tidal flats is orientated to the southwest, slowly turning southwards in the course of the flood tide. After slack water, the ebb current, flowing in an easterly direction, set in with velocities of about $0.05 \mathrm{~m} \mathrm{~s}^{-1}$. The highest ebb-velocities $\left(0.2 \mathrm{~m} \mathrm{~s}^{-1}\right)$ are reached just before emersion of the tidal flats (Fig. 4).

The calculation of near-bottom residual currents reveals a dominance of the flood phase. The residual current path at position IV (Fig. 5) attains a length of $650 \mathrm{~m}$ with a direction of $245^{\circ}$ and at position $\mathrm{V} 1000 \mathrm{~m}$ and $255^{\circ}$ respectively.

Near the tidal creek the maximum current velocities range from 0.4 to $0.5 \mathrm{~m} \mathrm{~s}^{-1}$. At location I and II (Fig. 2) the maximum values of current velocities are reached during the flood at position III; the highest velocity occurs during the ebb tide. Tidal currents in the eastern part of the creek are relatively balanced. North of the island of Uthörn, the average measured over 15 tides reveals idealized flow paths of $3430 \mathrm{~m}$ for the ebb period and $3640 \mathrm{~m}$ for the flood period. In the middle section of the tidal creek the residual currents are ebb-orientated, with idealized flow paths of $3850 \mathrm{~m}$ for the ebb period and $3210 \mathrm{~m}$ for the flood period, whereas in the head section the residual currents are once more flood-orientated, with idealized flow paths during flood $4000 \mathrm{~m}$ and during ebb $1930 \mathrm{~m}$ (Fig. 5).

In October 1991, current measurements were carried out during a period of strong westerly winds followed by strong easterly winds. Westerly storms result in a considerable piling up of water. The water level was about 1-1.5 $\mathrm{m}$ above the mean high water level for the period of two days. During this time, the measured near-bottom water movement in Königshafen was exclusivly directed into the bay. The idealized flow paths attained $10000 \mathrm{~m}$ for the position in the western part of the bay, for the other two stations at the creek up to $5000 \mathrm{~m}$ (Fig. 6).

By contrast, the tidal curve looks very different under the influence of easterly storms. The water level at high tide ranged about $0.5 \mathrm{~m}$ below mean high water level, so that wide areas of the tidal flats were not submerged. Under these conditions, the residual currents in the whole bay were mostly ebb-oriented. The idealized flow paths reached up to $6750 \mathrm{~m}$ for the ebb flow, while the flood reached idealized flow paths of 1500-2790 m (Fig. 7). 


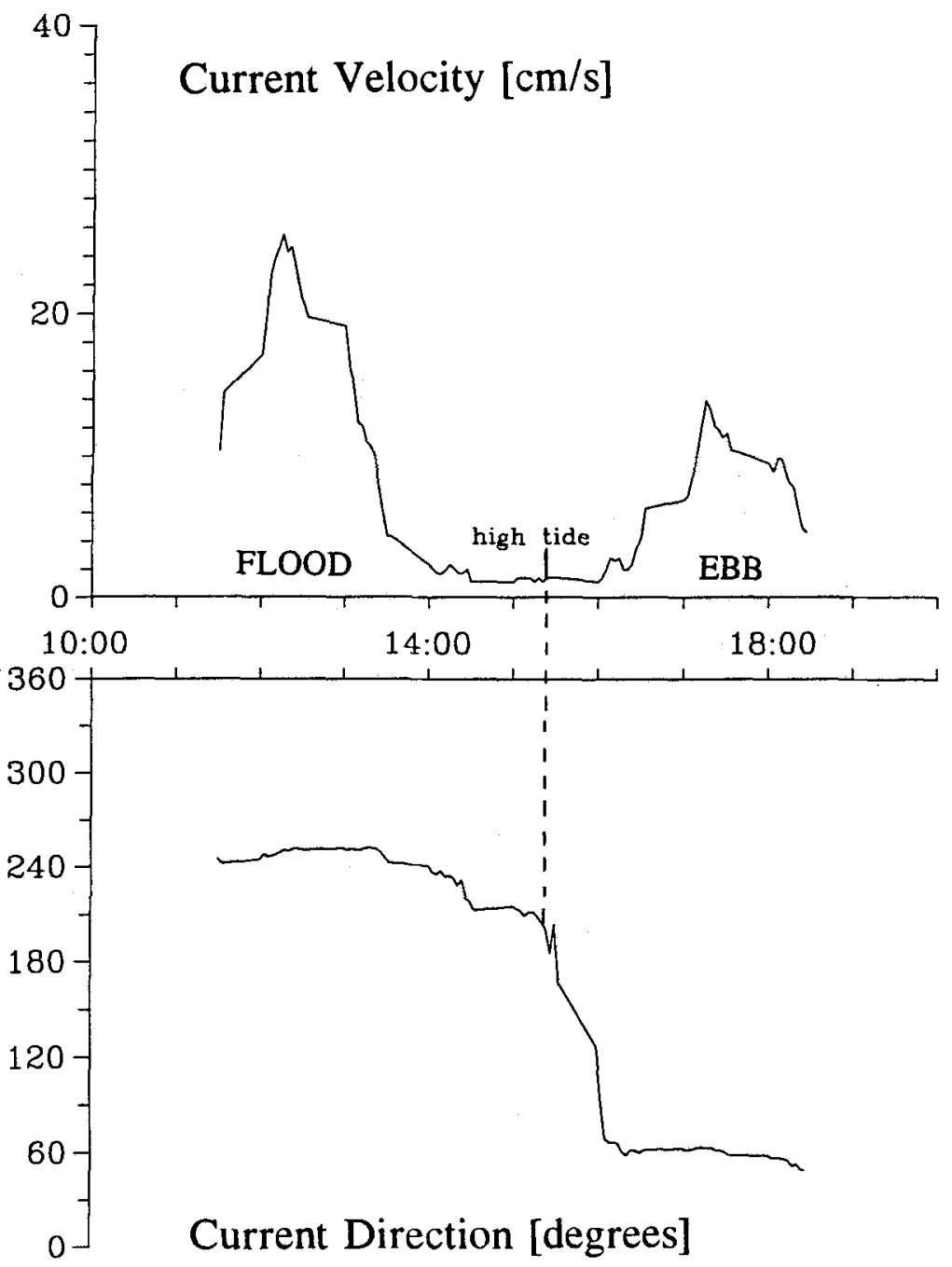

Time [h]

Fig. 4. Current velocity and direction over a tidal cycle at station IV, 11th June, 1990

The normal tidal cycle as described above was quickly regained after the decrease of both storm events.

\section{Suspended matter}

The concentration of suspended matter measured in Königshafen ranges between 4 and $15 \mathrm{mg} \mathrm{l}^{-1}$. Near the mouth of the tidal creek, the highest concentrations occur just before low tide with values of $10-12 \mathrm{mg} \mathrm{l}^{-1}$. At low water slack, the concentration of suspended matter decreases to $5 \mathrm{mg} \mathrm{l}^{-1}$, but rapidly increases on the start of the flood phase to $8-9 \mathrm{mg} \mathrm{l}^{-1}$ (Fig. 8).

A stratification of suspended matter can be observed in areas with a water depth 


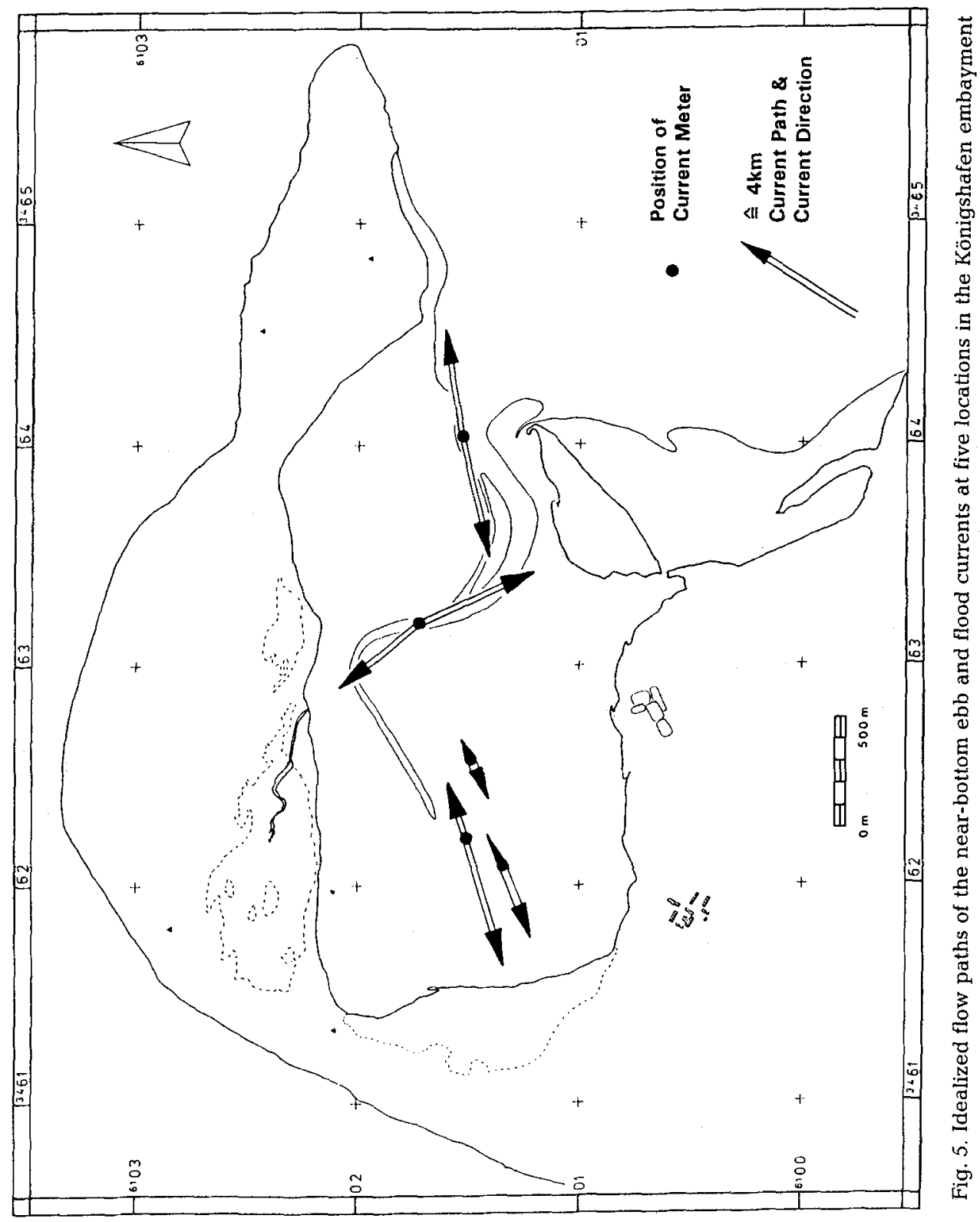




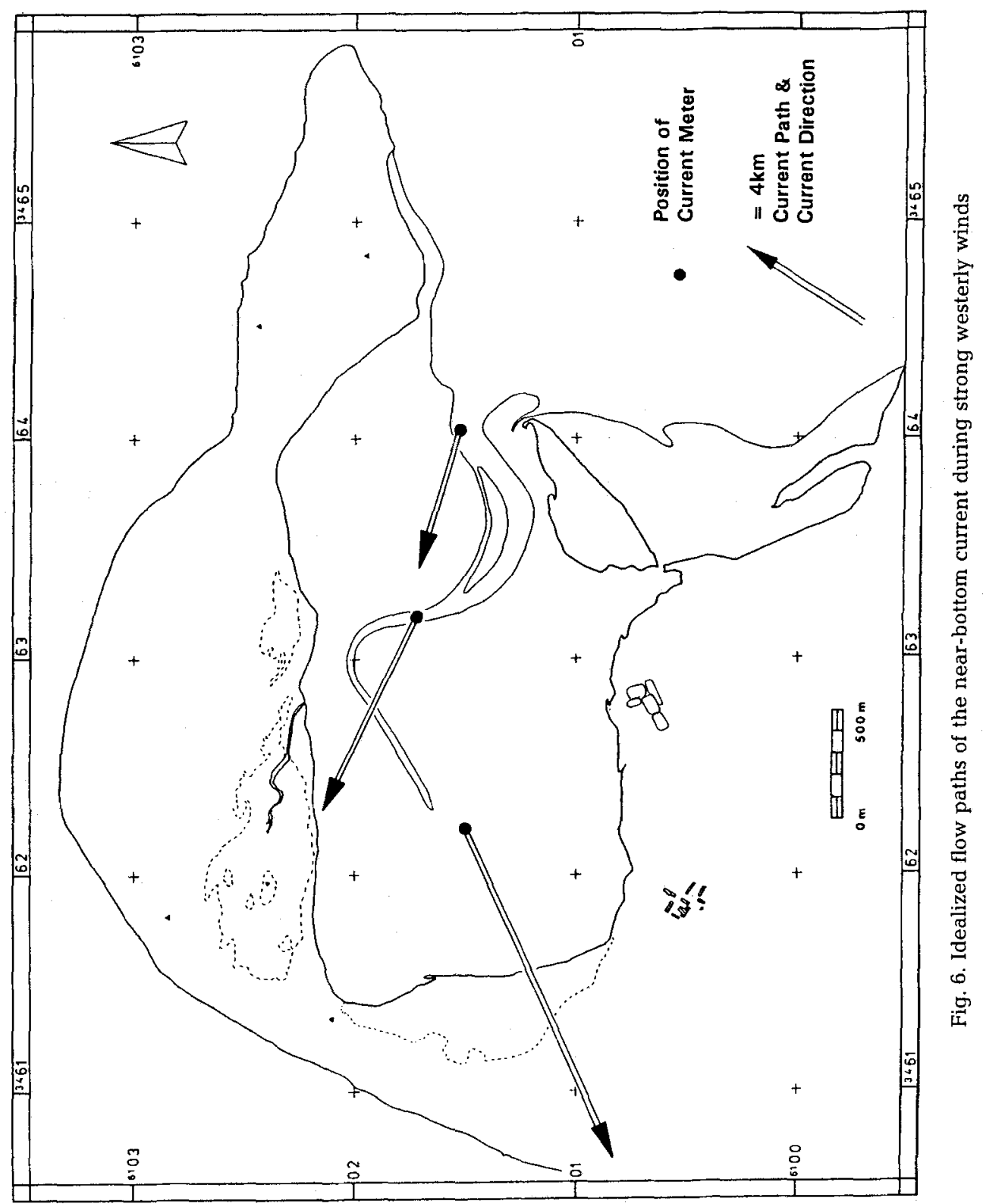




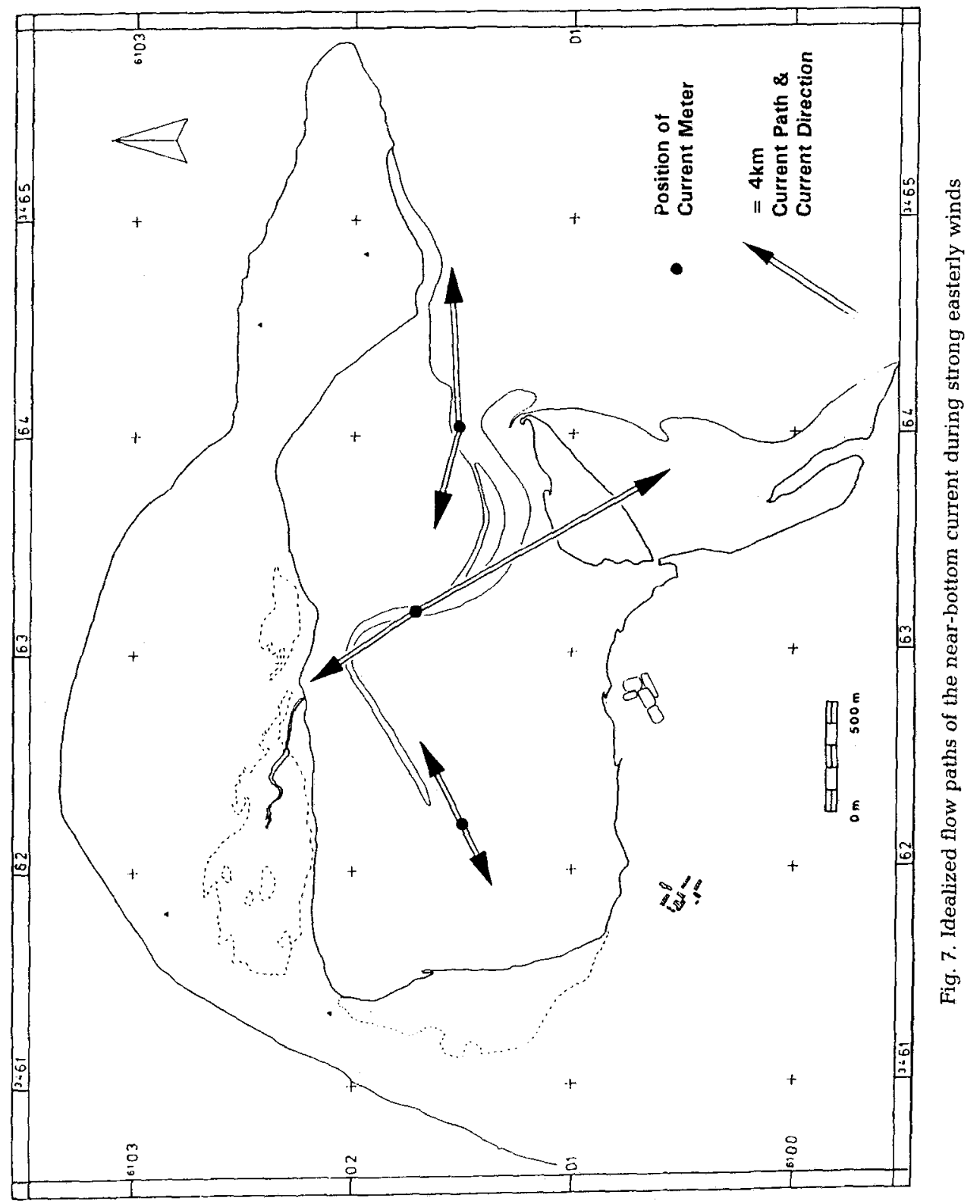


greater than $2 \mathrm{~m}$ (i.e. in the direct environment of the tidal creek) and in areas with concentrations of more than $10 \mathrm{mg} \mathrm{l}^{-1}$ in the near-surface water body. Such concentrations, like the extreme case of Königshafen, only occur in the western part above the mud flats. Over the greater part of the bay, the distribution of suspended matter in the water column is homogeneous. The lowest concentrations of suspended matter at high tide range from $0-2 \mathrm{mg} \mathrm{l}^{-1}$ and occur on the north-eastern tidal flats. Along the northern shoreline, the suspended matter content increases steadily in a westerly direction, attaining $10-15 \mathrm{mg} \mathrm{l}^{-1}$ in the innermost part of the bay. Along the southern shoreline, the concentrations decrease slowly from west to east. Nevertheless, in the southern part of Königshafen, the concentrations exceed those of the northern part by a factor of 1.5. A local minimum of suspended matter is observed in the middle of the bay (Fig. 9).

During storms, the distribution of suspended matter is strikingly different. In comparison to the situation described above, the concentration of suspended matter in the Königshafen embayment was elevated by a factor of 2-3 during the period of strong westerly winds (Fig. 10). During strong easterly winds, the concentrations even increase by a factor of 20 . Under such conditions, concentrations of more than $300 \mathrm{mg} \mathrm{l}^{-1}$ were measured at high tide in the western part of Königshafen (Fig. 11).

The grain size spectrum of suspended matter ranges between 1 and $300 \mu \mathrm{m}$. Polymodal distributions with modes at 10,35 and $50 \mu \mathrm{m}$ are typical. For this reason the measurements range was fixed between 0.5 and $150 \mu \mathrm{m}$ (Fig. 12). Suspended particles with diameters of more than $50 \mu \mathrm{m}$ mainly consist of organic matter, whereas particles in the range of $10-50 \mu \mathrm{m}$ are often composed of flocculated inorganic components. The flocs

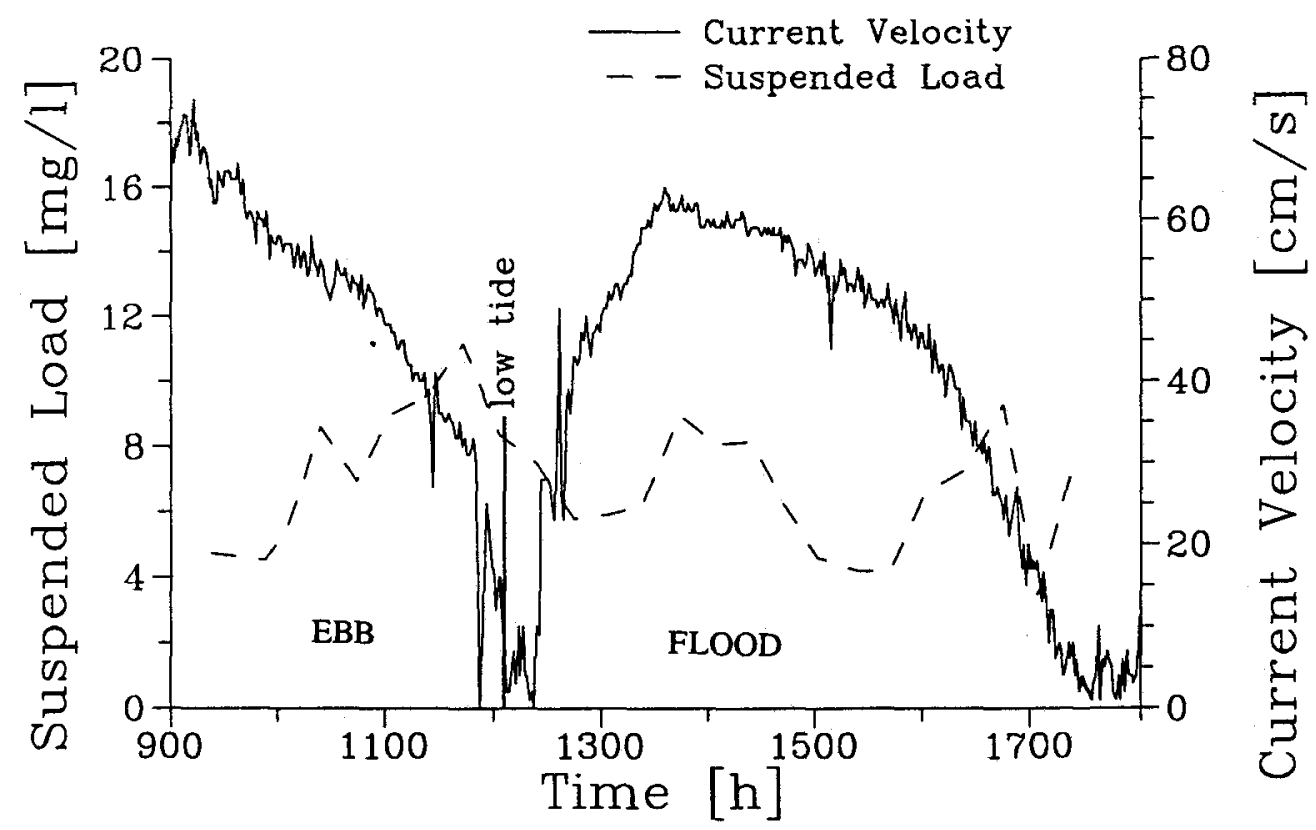

Fig. 8. Current velocity and concentration of suspended matter over a tidal cycle at a station in the tidal creek north of the island of Uthörn, 30th August, 1991 


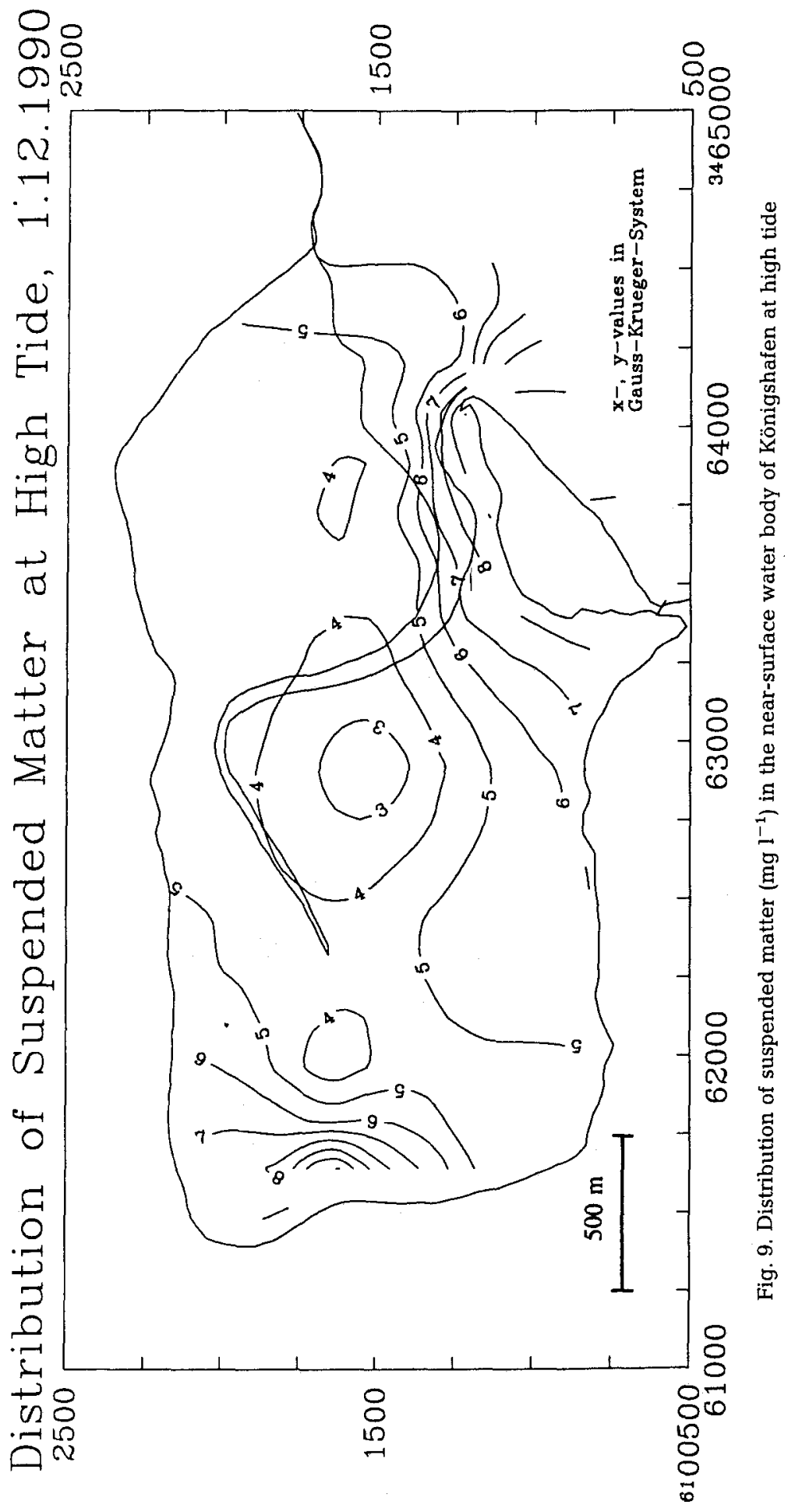




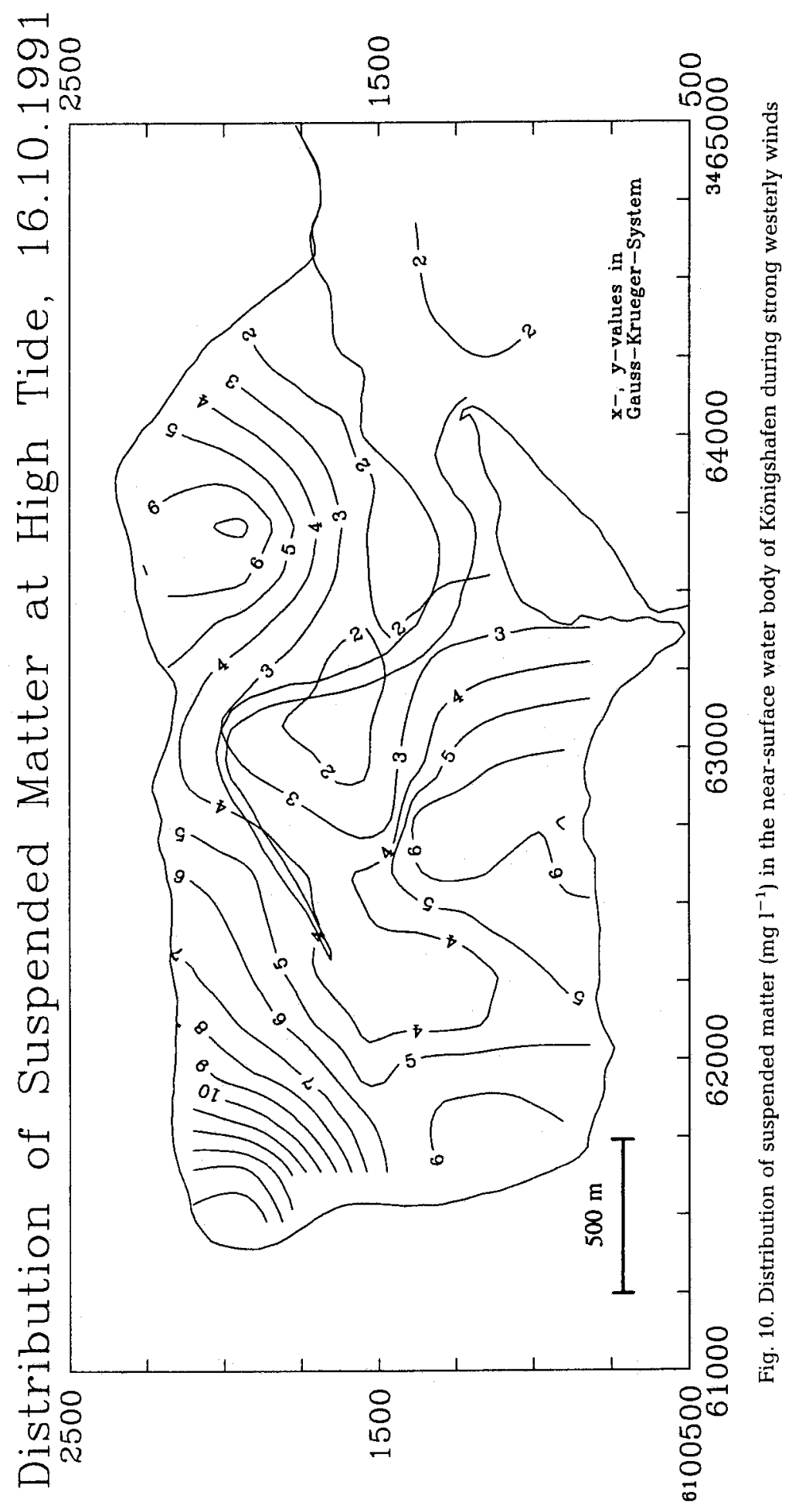




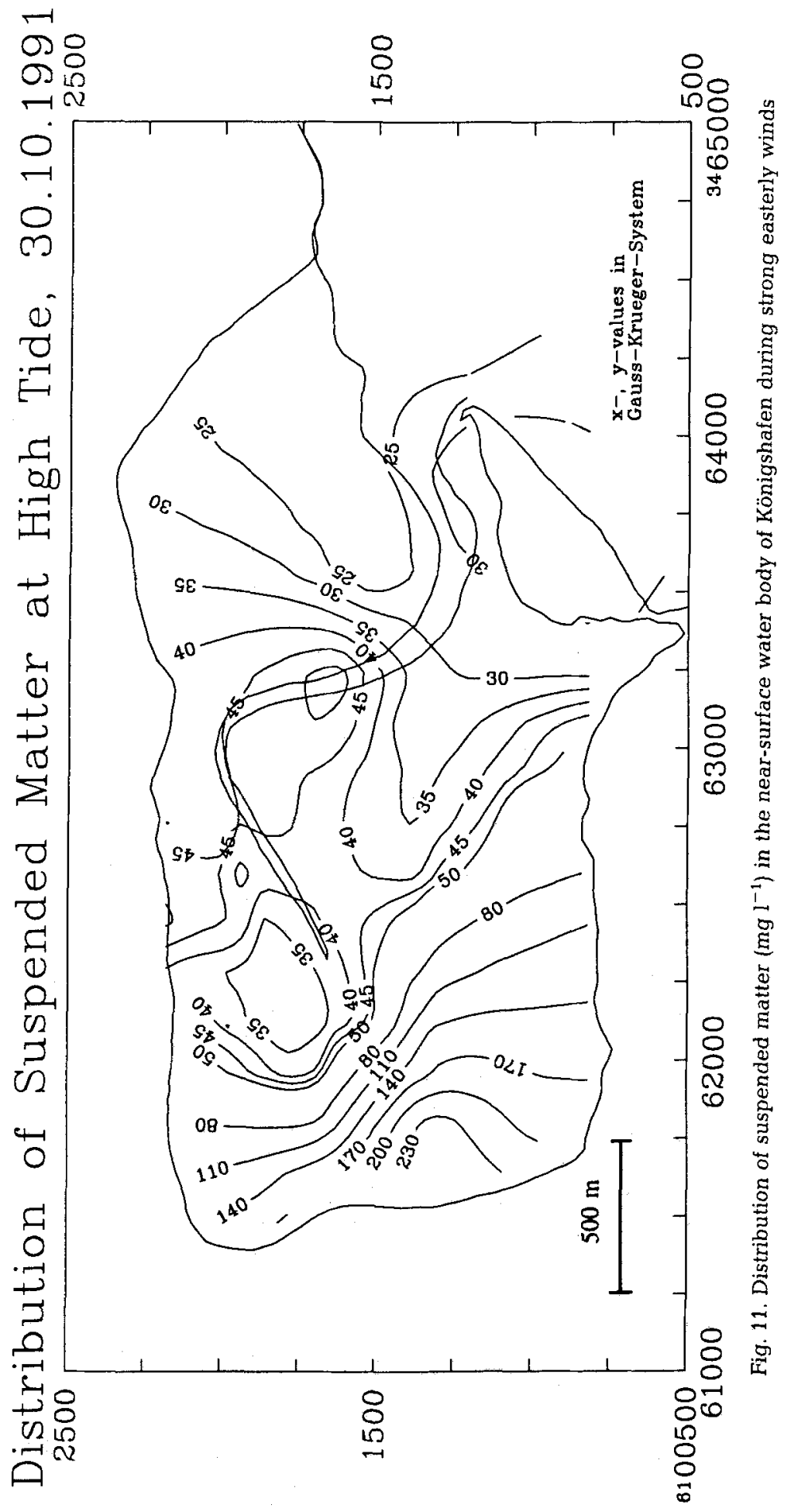




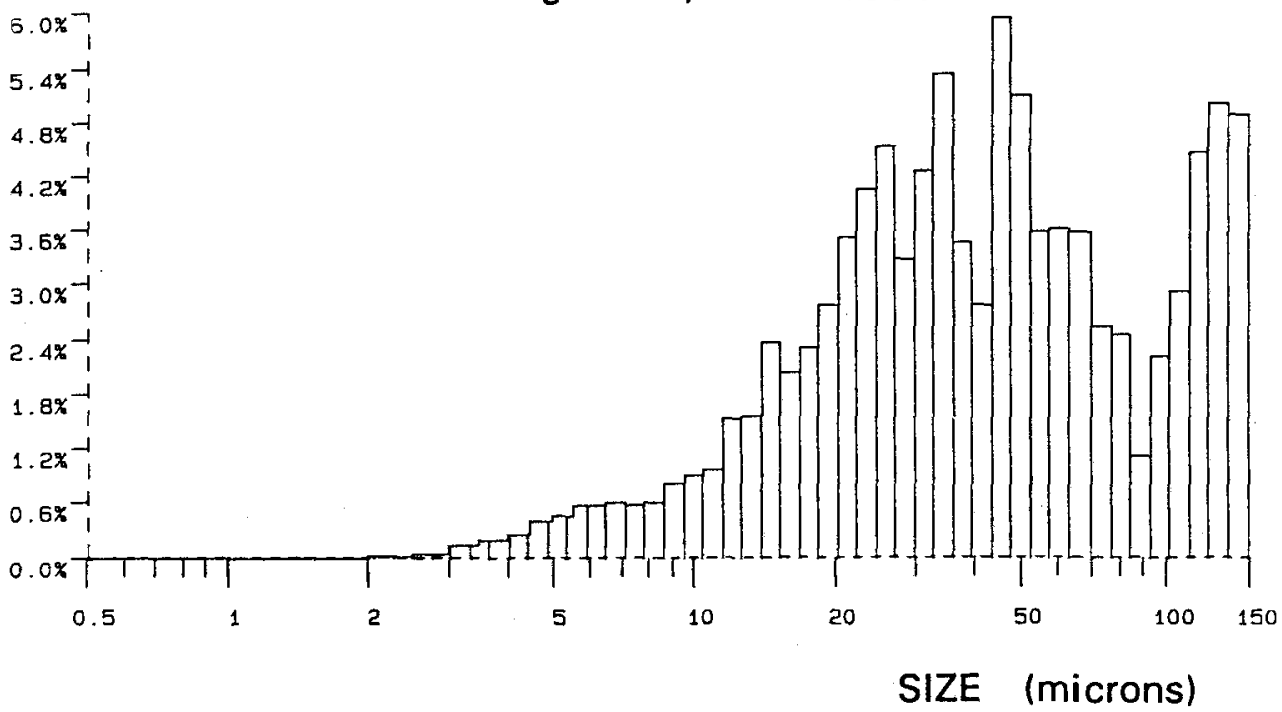

\section{GRAIN SIZE DISTRIBUTION} Königshafen, 28.08.1991

Fig. 12. Grain size distribution of suspended matter samples

mostly consist of particles about $5 \mu \mathrm{m}$ in size. The composition of the suspended matter in Königshafen is on the whole very inhomogeneous.

\section{DISCUSSION}

The current velocities measured in Königshafen are of the same magnitude as those reported in the literature for other Wadden Sea regions of the coast (Siefert et al., 1986). After low tide, the onset of water movement at first follows the morphology of the tidal flats. As soon as the more elevated flats are submerged (about 2-3 h after low tide), the water flows through the Königshafen embayment in the form of a large anti-clockwise eddy system. This eddy system remains intact as long as the tidal flats are submerged. As soon as the flats emerge, the eddy breaks down and the water is channelized through the depressions and the main creek. As a result of the eddy system, the northern part of the bay can be defined as the preferred zone for the inflowing water and the southern part for the outflowing water.

On the tidal flats and in the western part of the tidal creek, flood currents dominate the tidal curve. According to Van Straaten \& Kuenen (1957), Postma (1961) and Dronkers (1984), flood-dominated residual currents should induce a transport of material into the bay. Pejrup \& Bartholdy (pers. comm.) calculated a depositional rate of $5.1 \mathrm{~kg} \mathrm{~m}^{-2} \mathrm{y}^{-1}$ in the mud areas of Königshafen on the basis of their own measurements.

The weak ebb-dominance of the tidal processes at station III in the middle part of the main tidal creek is caused by the morphological structure of the bay. Three hours after high water, the whole western part of Königshafen is drained by the tidal channel. Since 

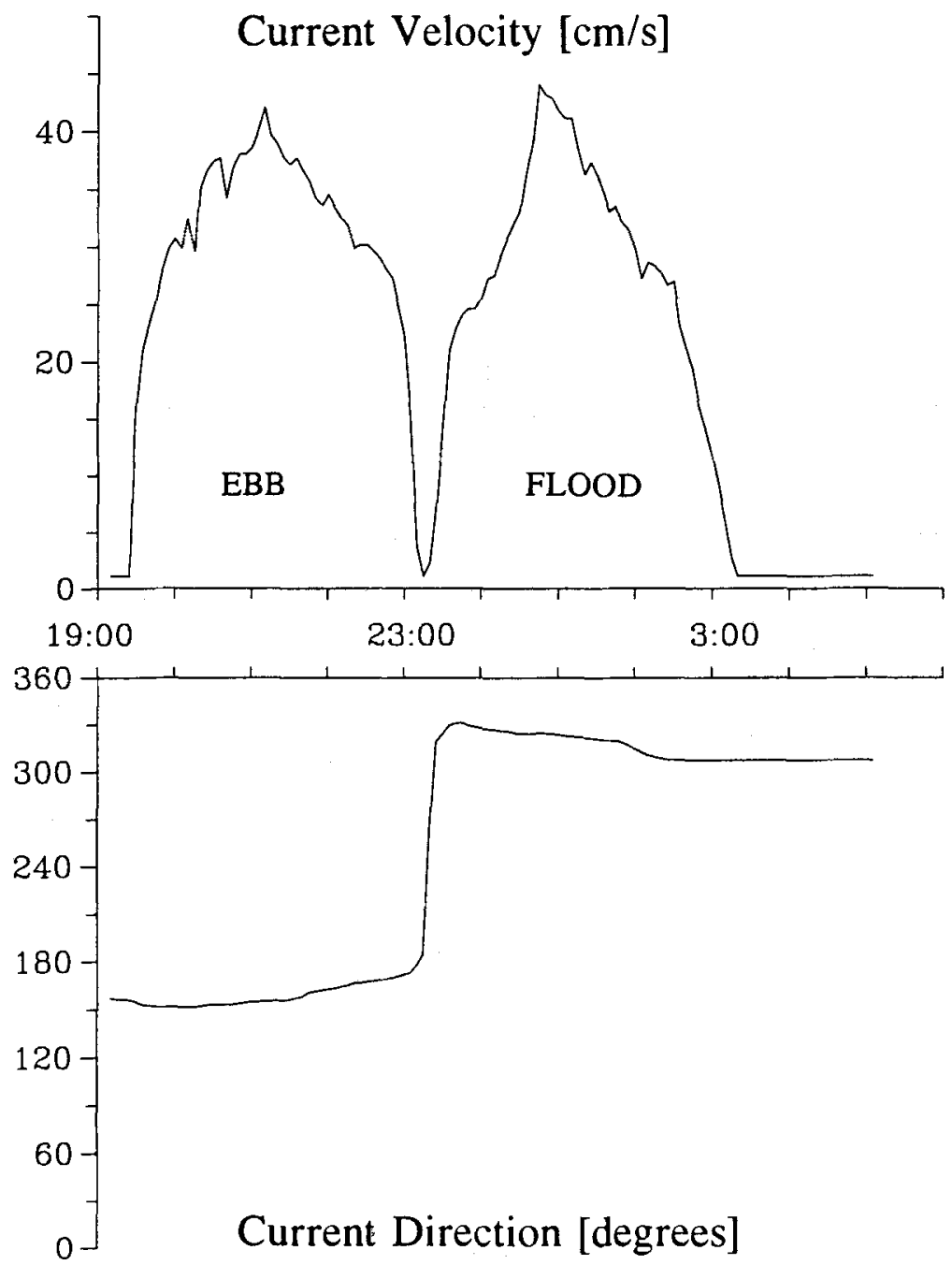

Time $[\mathrm{h}]$

Fig. 13. Current velocity and direction over a tidal cycle at position III, 26th/27th August, 1991

the channel is very narrow in the middle section, it causes an acceleration of the outflowing water, generating current velocities occasionally exceeding $0.5 \mathrm{~m} \mathrm{~s}^{-1}$ (Fig. 13). The lower velocities of the inflowing water (about $0.45 \mathrm{~m} \mathrm{~s}^{-1}$ ) can be attributed to the smaller water mass passing through this part of the channel on the flooding tide because the main input of water does not begin before the tidal flats in the northern part have been flooded.

The current system outlined above is effectively influenced by storm events. The near-bottom inflow of water, observed during strong westerly winds, must be balanced by near-surface currents flowing in an easterly direction because there is no throughflow and the maximum volume of Königshafen has a defined limit. The near-surface flow out 


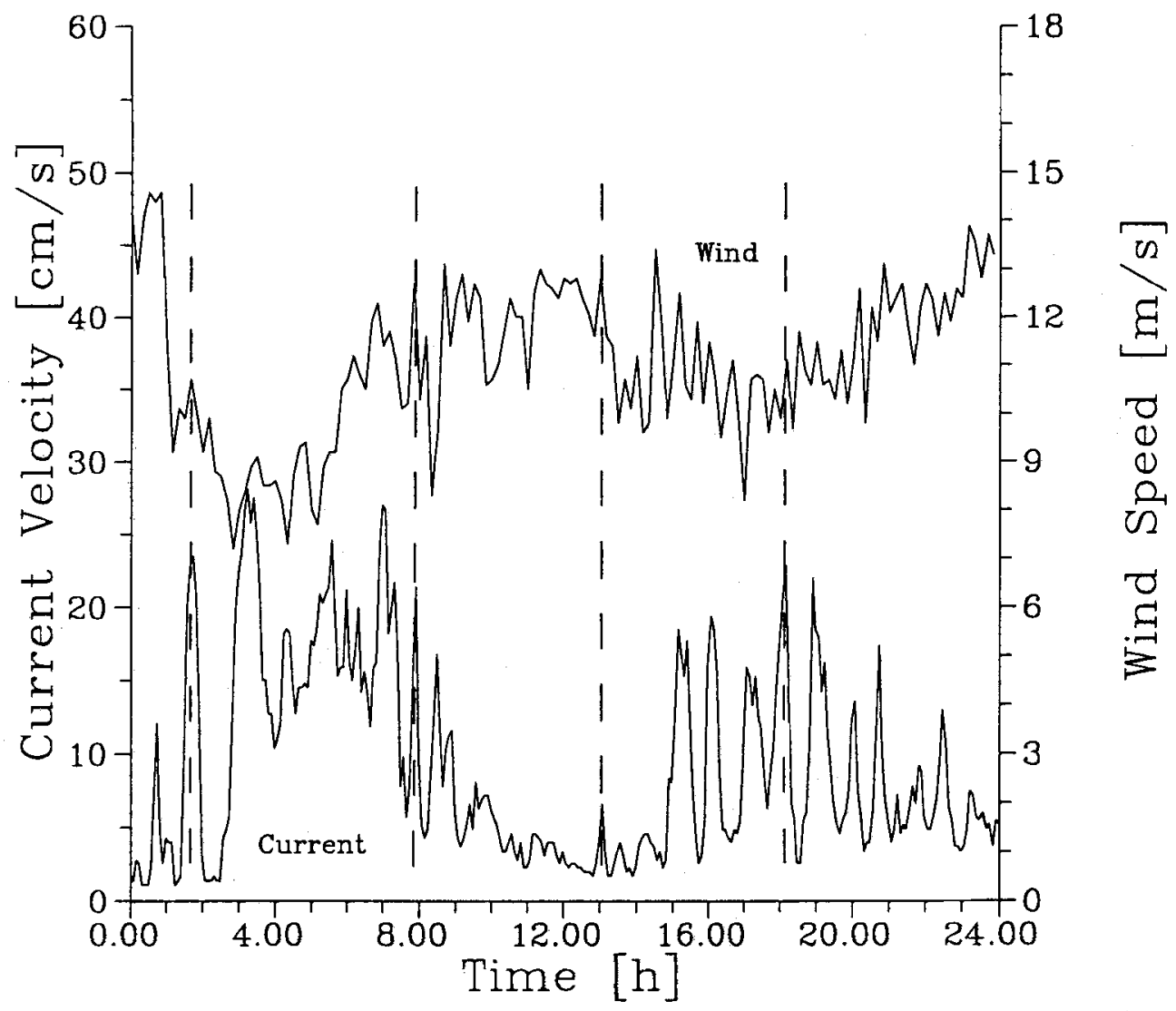

Fig. 14. Wind speed and near-bottom current velocity in Königshafen on 17th October, 1991

of the bay is intensified by wind-induced drift currents, which as a result further strengthen the near-bottom inflow. In Figure 14, the measured near-bottom current velocities are illustrated together with the wind velocities as a function of time. It can be seen that the short-term increase of wind energy can induce an enhancement of current velocities in the near-bottom layer without any time-lag. Since, during periods of strong westerly winds, the residual current vectors are exclusively directed into the bay, this has to result in increased sedimentation-rates. Sediment accretion, however, is not directly measurable, because the content of suspended matter in the inflowing water is very low and the turbulence in the water body is too high to allow sedimentation of suspended particles.

By contrast, the residual currents are ebb-orientated during strong easterly winds. An increase in the erosion of the tidal flats can be expected as a consequence of the strong ebb dominance of the tidal processes on the flats, but this is likewise not measurable. Reasons for this are the limits of measuring accuracy in shifting tidal areas (Runte, 1989) and the fact that the duration of storm events from easterly directions is 
usually restricted to a few days, thereby limiting the potential influence of change in the current patterns on the morphology of the tidal flats.

The concentration of suspended matter in the inflowing water masses during the flood period are of the same order as the concentration in the "Lister Tief". Fanger et al. (pers. comm.), comparing the transmission values measured in the tidal creek north of the island of Uthörn with the values of the open sea, mentions an "oceanic transmission" in Königshafen. In comparison to other tidal areas, such as the southern part of the NorthFrisian Wadden Sea (Nommensen, 1982), the concentration of suspended matter in Königshafen falls short by a factor of 5-10.

The spatial distribution pattern of suspended matter in the near-surface water is well correlated with the mud areas in the bay as mapped by Austen (1992). The consistent increase of suspended matter in the western part of the bay and in the central part of Königshafen is not only a consequence of the gradually increasing concentration of suspended matter caused by the hydrodynamics of the system (residual current vectors), but partly also due to the local resuspension of fine-grained sediment. The location of the turbidity maximum in the near-surface water body was not stationary, but varied with changing wind directions and strengths in the course of the survey. The drift current and the pronounced anti-clockwise flow in Königshafen leads to a drift transport of material along the southern shore of the embayment. Since the concentration of suspended matter in the in- and outflowing water in the tidal creek north of the island of Uthörn is of the same order, material is assumed to settle out of the water column at the same rate as it is resuspended in the mud areas.

The increased concentration of suspended matter in the embayment, measured during strong westerly winds, can be attributed for the most part to the enhanced resuspension caused by the intensified wave energy. The increased concentration of suspended matter in the north-eastern region, however, is caused by near-surface drift currents. A resuspension in this region can be excluded because the intertidal sediment is composed of medium to coarse sand (Austen, 1992).

Strong easterly winds generate relatively high waves in Königshafen and waveinduced erosion is further intensified by lowered water levels. Under these conditions, an enhanced resuspension can be observed in Königshafen and in the western part of the whole Sylt-Rømø Wadden Sea region. In Königshafen, the inflowing water, therefore, carries a higher load of suspended matter, which is further increased by wave-induced resuspension of mud at the mussel beds situated to the east of Königshafen. Indeed, under such externally forced conditions the concentration of suspended matter increases sharply, although the spatial distribution remains unchanged, the reason being the anticlockwise eddy that remains intact at times of strong easterly winds.

According to Austen (1992), the mud flats in the Königshafen embayment are very stable in shape and location and the sediment budget of the bay is balanced. Pejrup \& Bartholdy (pers. comm.) calculated a sedimentation rate of $1275 \mathrm{t} \mathrm{y}^{-1}$ in the mud areas of the Königshafen and $900 \mathrm{t}^{-1}$ on the adjacent salt marshes. From these sedimentation rates, they concluded that under the present hydrodynamic conditions $1 \mathrm{mg}$ of particulate matter per litre of water should precipitate in the course of every tide. Disregarding the storm events, the mean concentration of suspended matter in the inflowing, as well as in the outflowing, water north of the island of Uthörn ranges between 4 and $5 \mathrm{mg} \mathrm{l}^{-1}$. The water volume of Königshafen amounts to $5.58 \cdot 10^{6} \mathrm{~m}^{3}$ at mean high water and $0.59 \cdot 10^{6} \mathrm{~m}^{3}$ 
at mean low water (Hartke, pers. comm.). Thus, during each semitidal cycle, $4.99 \cdot 10^{6} \mathrm{~m}^{3}$ flow in and out, respectively. Assuming an average concentration of $5 \mathrm{mg} \mathrm{l}^{-1}$, the in- and outflowing water contains approximately $25 \mathrm{t}$ of suspended matter in each case. Under normal weather conditions, the water body in the Königshafen embayment contains about $30 \mathrm{t}$ of suspended matter at high tide. The difference of $5 \mathrm{t}$ between the in-/outflowing water and the content of suspended matter at high tide is explained by the resuspension of fine-grained sediment during each semi-tide and the suspended matter in the residual water in the tidal creek at low tide. This preliminary estimate provides a first impression of the order of magnitude of the expected suspended matter dynamics in a tidal embayment which can sedimentologically be regarded as being very stable.

Acknowledgements. This study was supported by the Federal Ministry of Research and Technology as part of the "Ecosystem Research in the Schleswig-Holstein Wadden Sea" (project-no. 03F0006D). It is publication no. 121. The project is coordinated by the Regional Office of the National Park Schleswig-Holstein Wadden Sea. Special thanks are due to Prof. Dr. Köster and Dr. K. Ricklefs for their untiring effort for the project and the continual willingness for discussion. Furthermore, I want to thank Dr. C. Gätje and all other persons involved in SWAP for good cooperation and the exchange and discussion of results.

\section{LITERATURE CITED}

Austen, I., 1992. Geologisch-sedimentologische Kartierung des Königshafens (List/Sylt). - Meyniana $44,45-52$.

Dronkers, J., 1984. Import of fine marine sediments in tidal basins. - Publ. Ser. Neth. Inst. Sea Res. $10,83-105$.

Göhren, H., 1969. Die Strömungsverhältnisse im Elbmündungsgebiet. - Hamb. Küstenforsch. 6 , $1-82$.

Nommensen, B., 1982. Die Sedimente des südlichen Nordfriesischen Wattenmeers (Deutsche Bucht). Diss., Univ. Kiel, 268 pp.

Postma, H., 1961. Transport and accumulation of suspended matter in the Dutch Wadden Sea. Neth. J. Sea Res. 1, 148-190.

Runte, K.-H., 1989. Methodische Verfahren zur Quantifizierung von Umlagerungen in intertidalen Sedimenten. - Meyniana 41, 153-165.

Siefert, W., Fahse, H., Gärtner, J. \& Niemeyer, H.-D., 1986. Die Strömungsverhältnisse in drei Langzeit-MeBprofilen im Küstenvorfeld der Deutschen Bucht. - Küste 43, 1-46.

Straaten, L. M. J. U. van \& Kuenen, Ph. H., 1957. Accumulation of fine-grained sediments in the Dutch Wadden Sea. - Geologie Mijnb. 19, 329-354. 